\title{
Body weight, scrotal circumference and testosterone concentration in young Boer goat males born during the dry or rainy seasons
}

\author{
F.Q.G. Bezerra, C.R. Aguiar Filho, L.M. Freitas Neto, E.R. Santos Junior, R.M. Chaves, \\ E.M.P. Azevedo, M.H.B. Santos, P.F. Lima and M.A.L. Oliveira\# \\ Laboratório de Biotécnicas Reprodutivas do Departamento de Medicina Veterinária, UFRPE, Av. Dom Manoel de \\ Medeiros s/n, Dois Irmãos, 52171 900, Recife/PE, Brazil
}

\begin{abstract}
The aim of this study was to compare testosterone concentration, body weight, scrotal circumference and age to penis detachment from days 30 to 240 in young Boer goat males $(n=22)$ born during the dry $(n=$ $11)$ and the rainy $(n=11)$ seasons. In the dry season the parameters varied as follows: body weight from 3.7 \pm 1.1 to $34.0 \pm 4.7 \mathrm{~kg}$, scrotal circumference from $7.9 \pm 0.8$ to $25.7 \pm 2 \mathrm{~cm}$, and testosterone concentration from $259.4 \pm 172.4$ to $4613.4 \pm 2892 \mathrm{pc} / \mathrm{mL}$. In the rainy season parameters varied as follows: body weight from $9.7 \pm 2.3$ to $28.1 \pm 6.9 \mathrm{~kg}$, scrotal circumference from $9.5 \pm 1.5$ to $22.0 \pm 3.0 \mathrm{~cm}$ and testosterone from $521.9 \pm 311.3$ to $3417.9 \pm 2021.8 \mathrm{pc} / \mathrm{mL}$. At three months of age, $70 \%$ of animals born during the rainy season presented with penis detachment, compared to $67.6 \%$ of animals born during the dry season at five months of age. Penis detachment occurred in all males at four and seven months for animals born in the rainy and dry seasons, respectively. There was a positive correlation between testosterone concentration and body weight in the dry $(r=0.30)$ and rainy $(r=0.43)$ seasons, between testosterone and scrotal circumference in the dry $(r=0.42)$ and rainy $(r=0.52)$ seasons, and between body weight and scrotal circumference in the dry $(r=0.93)$ and rainy $(r=0.88)$ seasons. The animals born during the rainy season showed earlier development in all the evaluated parameters than animals born during the dry season. It was found that scrotal circumference is directly correlated to body weight and testosterone concentration.
\end{abstract}

Keywords: Scrotal circumference, testosterone, young male goats, puberty, sexual maturity

${ }^{\#}$ Corresponding author. E-mail: maloufrpe@uol.com.br

\section{Introduction}

Testosterone is the most important male reproductive hormone; it is related to reproductive behaviour, spermatogenesis and secondary sexual characteristics (Hafez, 2004). The early reproductive behaviour (mounting) displayed by Boer goats long before the start of puberty has been associated with low testosterone production by the testicles after birth (Skinner, 1970).

It is important to evaluate testosterone levels to determine the development of the reproductive system of exotic goats that are adapted to the semi-arid climate of northeastern Brazil. Testosterone levels are useful in the selection of young sires and to characterise sexual maturity in different breeds (Eloy \& Santa Rosa, 1998). Plasma testosterone concentrations are related to age (Silva, 2000), season of the year (Delgadillo \& Chemineau, 1992), protein intake (Azevedo Neto, 2005) and luteinising hormone (LH) pulse frequency (Muduuli et al., 1979; Delgadillo \& Chemineau, 1992). Testosterone is directly involved in the onset of puberty, and consequently in the onset of spermatogenesis (Eloy \& Santa Rosa, 1998).

Age, weight at birth, weight gain, scrotal circumference (SC) and penis detachment are important puberty indicators in goats (Girão et al., 1996; Eloy \& Santa Rosa, 1998; De La Vega et al., 2001). However, there is no consensus as to which is the most important puberty indicator (Louw \& Joubert, 1964; Elwishy \& Elsawaf, 1971; Bongson et al., 1982; Traldi, 1983; Simplício et al., 1988; Maia, 1990). Puberty is defined as the moment when the male displays sexual behaviour that leads to mating and the ejaculate contains enough live, viable sperm to impregnate a female (Hulet \& Shelton, 1988; Jimeno et al., 2001). The display of mating behaviour is an important criterion for male selection since early sexual behaviour allows for the evaluation of reproductive capacity of an animal that will be used to intensify genetic selection and shorten the generation gap (Madani \& Rahal, 1988).

Breed-specific information is crucial for good reproductive management of a herd, such as for the adoption of key herd management practices and determining when animals are capable of reproduction. For 
this reason, and because only a few studies have been carried out to date on the effect of the season of birth (dry or rainy season) on plasma testosterone concentration, body weight, penis detachment and scrotal circumference of young male goats, the aim of this study was to evaluate the effect of the season of birth on the onset of sexual maturation of young Boer goat males in the semi-arid region of northeastern Brazil.

\section{Materials and Methods}

For the purpose of this study 22 male Boer goats (Capra hircus) born from single pregnancies were used. Of these, 11 were born during the dry season (dry season), and had an average weight at birth of $3.12 \pm 0.73$ $\mathrm{kg}$, and 11 were born during the rainy season (rainy season), and had an average weight at birth of $3.87 \pm$ $0.79 \mathrm{~kg}$. The animals were the property of Estação Experimental Benjamim Maranhão (EMEPA), located in the county of Campo de Santana, 150 km from the capital João Pessoa, Paraíba State, Brazil.

The climate is classified as warm semi-arid, with $465 \mathrm{~mm}$ average annual rainfall and $24{ }^{\circ} \mathrm{C}$ average annual temperature. The dry season starts in July and ends in January, with $15 \mathrm{~mm}$ average monthly rainfall. The rainy season starts in February and ends in June, with $72 \mathrm{~mm}$ average monthly rainfall. March and April are the months with the highest rainfall.

Animals were weaned at 90 days of age at that time the average weight was $11.35 \pm 2.45 \mathrm{~kg}$ for dry season animals and $16.26 \pm 3.1 \mathrm{~kg}$ for rainy season animals. Animals were kept under a semi-intensive production system: in the morning animals were let out on pasture of native caatinga vegetation and planted buffalo grass (Cenchrus ciliaris L.). In the afternoon animals were brought in for supplementation with $250 \mathrm{~g}$ Tifton hay (Paspalum notatum) and $100 \mathrm{~g}$ commercial feed for young goats [180 g Crude Protein (CP) - Caprinotech, Purina ${ }^{\circledR}$ ], and $150 \mathrm{~g}$ EMEPA concentrated feed (150 g CP/ $/ \mathrm{kg}$ ) with an estimated $52.2 \%$ total digestible nutrients (TDN) for each animal. Animals had access to water and mineral salt ad libitum.

Husbandry practices included deworming and preventive treatment for clostridiosis. All does were vaccinated against clostridiosis four to six weeks prior to parturition. Offspring were first vaccinated at 60 days of age and received a booster vaccination 45 days later. Does were dewormed with albendazol at 150 days of gestation and offspring were dewormed at weaning.

For the purpose of this study, 30-day-old males, born during the rainy season or dry season, were evaluated eight times, at 30-day intervals.

Body weight and SC were measured and penis detachment evaluated. Penis detachment was scored on a scale from zero to five $(0=$ completely adhered, $5=$ completely detached $)$, as described by Wiggins \& Terril (1953) for rams. For penis detachment evaluation the animals were placed in a sitting position while the penis "S" was straightened and the preputium pulled down in order to expose the penis.

On days 30, 90, 150, 180, 210 and 240 blood samples were collected in Vacutainer ${ }^{\circledR}(10 \mathrm{~mL})$ tubes, and centrifuged at $3000 \mathrm{~g}$ for $10 \mathrm{~min}$. Plasma samples were stored in $1.5 \mathrm{~mL}$ plastic container (Eppendorf ${ }^{\circledR}$ ) at $-20{ }^{\circ} \mathrm{C}$ until determination of testosterone concentration.

Total testosterone concentration (TC) analysis was performed in duplicate using electrochemical luminescence (ECL), a competitive test using a testosterone specific monoclonal antibody (Passing \& Bablok, 1983; Eastone \& Decker, 1997). Roche Elecsys 1010/2010 and Modular analytics E170 (Roche, Switzerland) were used to determine plasma testosterone concentration. Results were expressed in picograms per $\mathrm{mL}(\mathrm{pc} / \mathrm{mL})$.

Data were submitted to Pearson partial correlation analysis (SAS, 1990) and an average comparison test (t-Student), with a 5\% significance level.

\section{Results}

Testosterone concentration in animals born during the dry season varied from $259.4 \pm 172.35$ to $4613.4 \pm 2892.02 \mathrm{pc} / \mathrm{mL}$, and TC in animals born during the rainy season varied from $521.9 \pm 311.27$ to $3417.9 \pm 2021.77 \mathrm{pc} / \mathrm{mL}$. It was noticed that until six months of age animals born during the rainy season had higher TC values $(\mathrm{P}<0.05)$, but at seven and eight months $\mathrm{TC}$ values were higher $(\mathrm{P}<0.05)$ in animals born during the dry season (Figure 1). In the case of animals born during the dry season, the TC profile did not change during the first five months $(\mathrm{P}>0.05)$ of the experiment (Figure 1); yet from five to seven months of age TC values increased $(\mathrm{P}<0.05)(4613.4 \mathrm{pc} / \mathrm{mL})$, and then decreased drastically $(\mathrm{P}<0.05)$ until eight months of age $(1721.7 \mathrm{pc} / \mathrm{mL})$. Animals born during the rainy season presented a constant increase $(\mathrm{P}<0.05)$ in TC levels until seven months of age $(3417.9 \mathrm{pc} / \mathrm{mL})$, when a marked decrease was observed $(\mathrm{P}<0.05)$ until eight months of age (1576.1 pc/mL). 


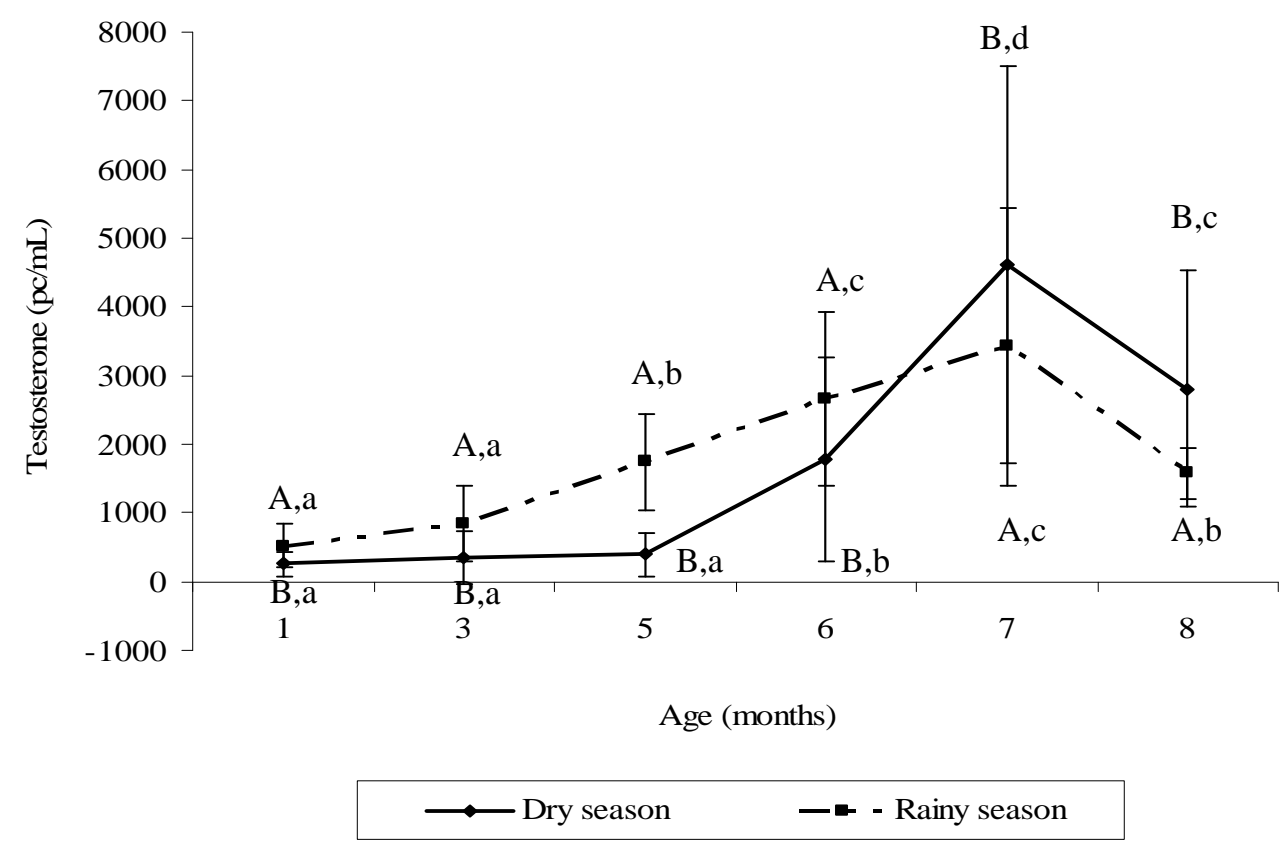

Figure 1 Plasma testosterone profiles for the first 8 months of age in young Boer goat males born during the dry and rainy seasons. Different superscripts (lowercase within a line and uppercase between lines at the same age) differ significantly at $\mathrm{P}<0.05$.

Figures 2 and 3 display body weight and SC results. Figure 2 illustrates that in both groups body weight increased with age. Animals born during the rainy season were heavier until seven month of age $(\mathrm{P}<0.05)$, but at eight months no difference in mean body weight was noticed between groups. Figure 3 shows that in the case of animals born during the rainy season, there was a steep increase in SC until four months of age, while in the case of animals born during the dry season this increase in SC was evident only after five months of age.

At three months of age $70 \%$ of animals born during the rainy season presented with penis detachment, whereas $67.6 \%$ animals born during the dry season presented with penis detachment at five months of age. All animals in the rainy season and dry season groups presented with penis detachment at seven months of age.

Positive correlations between testosterone and body weight $(r=0.30 ; r=0.43)$, testosterone and SC $(r=0.42 ; r=0.52)$, and body weight and SC $(r=0.93 ; r=0.88)$ were noted for dry season and rainy season animals, respectively.

\section{Discussion}

Body development (weight gain) was delayed in animals born during the dry season, while animals born during the rainy season were heavier and had higher TCs and higher SC results $(\mathrm{P}<0.05)$ during the first five months of age. However, later, from seven months of age, the dry season animals had higher testosterone levels $(\mathrm{P}<0.05)$ and similar SC values. These results indicate that the delay in body growth, testicular growth and TC are outweighed when animals born in an unfavourable dry season are later exposed to good feeding. In goats, the excess or lack of feed protein affects TCs (Azevedo Neto, 2005). 


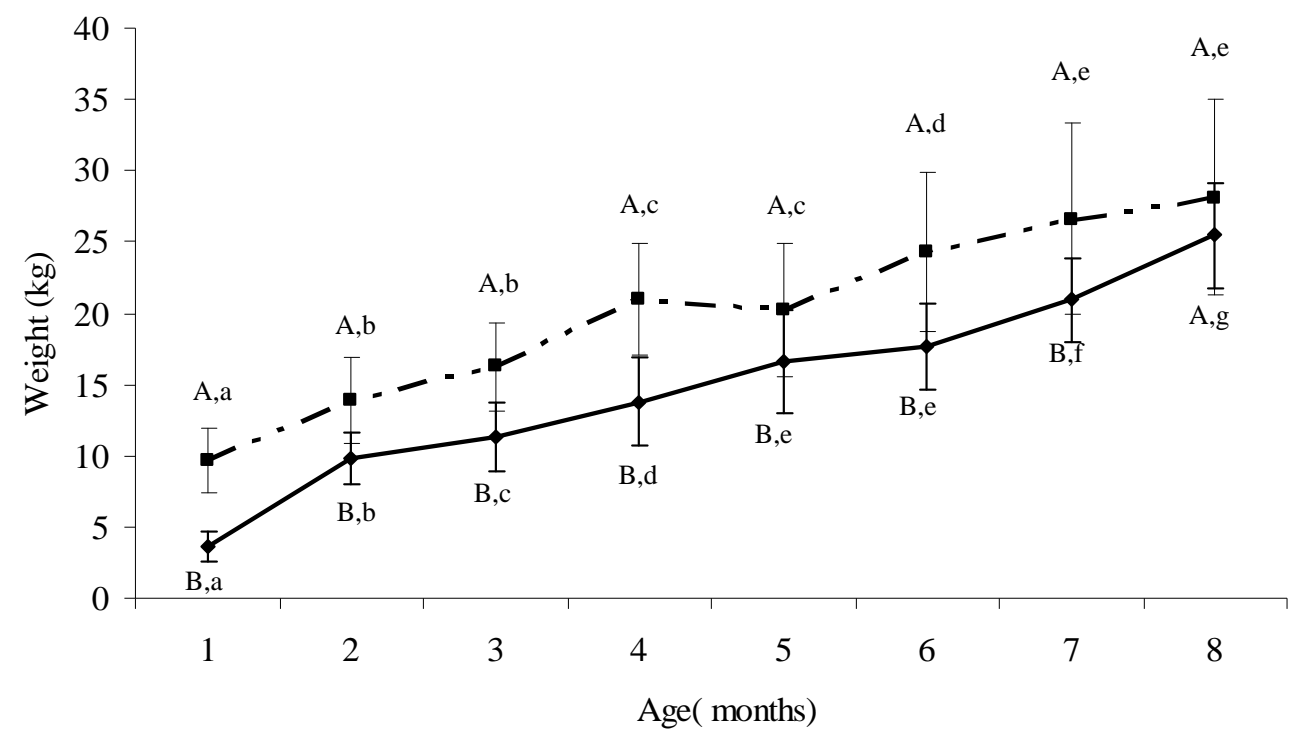

$\longrightarrow$ Dry season ——- Rainy season

Figure 2 Body weight changes during the first eight months of age in young Boer goat males born during the dry and rainy seasons. Different superscripts (lowercase within a line and uppercase between lines at the same age) differ significantly at $\mathrm{P}<0.05$.

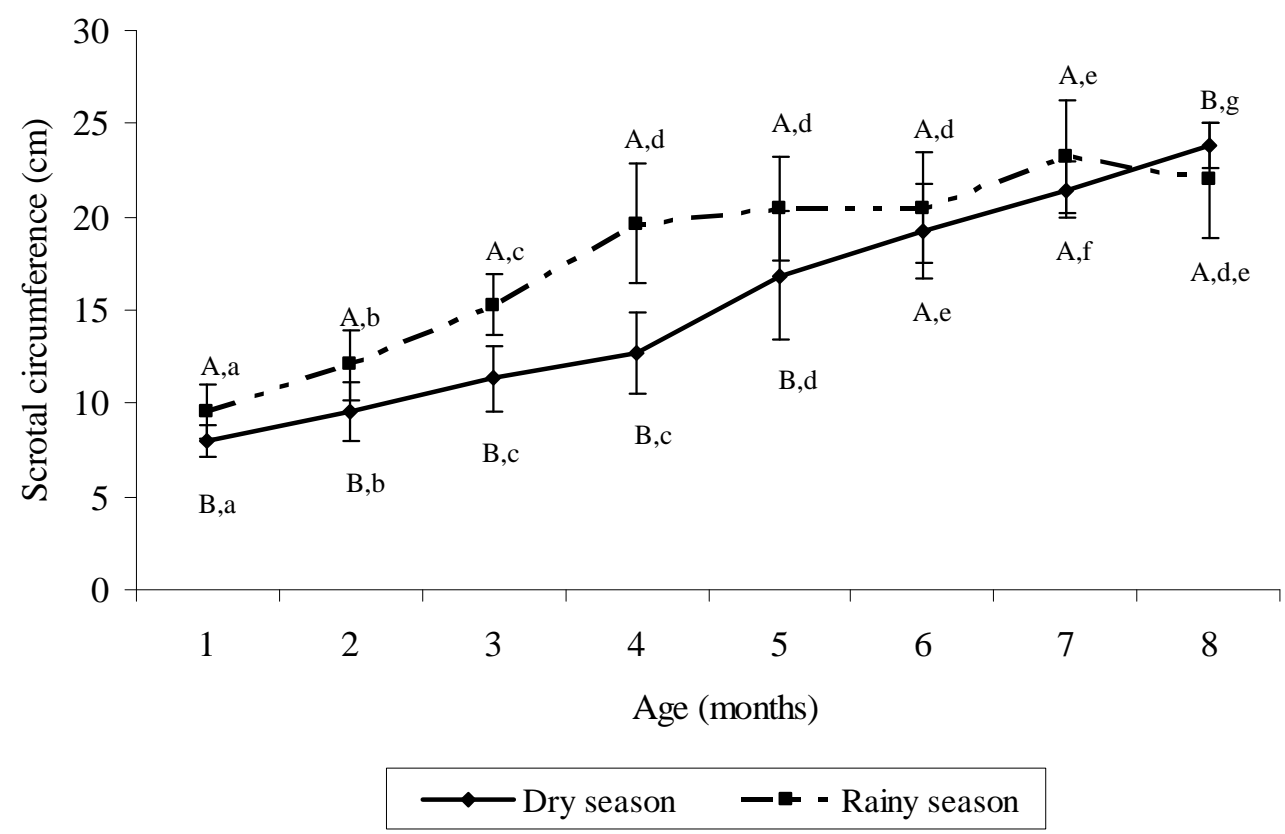

Figure 3 Scrotal circumference changes during the first eight months of age in young Boer goat males born during the dry and rainy seasons. Different superscripts (lowercase within a line and uppercase between lines at the same age) differ significantly at $\mathrm{P}<0.05$. 
In young Saanen and British Alpine goats, testosterone profiles are marked by a decline followed by a peak at the time when males reach sexual maturity (Macmillan \& Hafs, 1969; Ahmad et al., 1996). In the case of animals born during the rainy season the TC increased until seven months of age, after which there was a marked decrease. This was similar to the observations of Silva (2000) in Saanen goats.

The testosterone decrease after seven months of age might be a result of the aromatisation of testosterone to oestradiol in the central nervous system and its negative effect on the hypothalamus (Auclair et al., 1995; Scott et al., 1997) and hypophysis (Olster \& Foster, 1986).

Sexual maturation (puberty), especially in males, is an extremely complex process that cannot be defined by a single event (Wiggins \& Terril, 1953). Penis detachment is an indicator of sexual maturity. Animals born during the rainy season presented with penis detachment at three to four months of age, while in animals born during the dry season penis detachment occurred between five and seven months of age. Our results are in agreement with those of other authors who reported that the start of sexual maturity varies from 123 to 242 days (Elwishy \& Elsawaf, 1971; Nunes, 1982; Traldi, 1983; Simplício et al., 1988; Girão et al., 1996).

According to Johnstone (1948) and Eloy \& Santa Rosa (1998), testicular hormones play an important role in penis detachment. The current study confirms this, since it was noticed that penis detachment coincides with increases in TC. It is interesting to note that this relation was more evident in animals born during the dry season, and which, prior to the hormonal peak, presented low levels of testosterone. Furthermore, it is important to emphasise the close relationship between TC, body weight and SC (Trejo et al., 1988; Eloy \& Santa Rosa, 1998; Silva, 2000). The significant compensatory development observed in the animals born during the dry season, between six and eight months, occurred during the subsequent rainy season, when the nutritional value of the pasture was higher.

\section{Conclusions}

Taking all the reported results into consideration, it can be concluded that the animals born during the rainy season have earlier sexual maturity, in terms of all the evaluated parameters. Scrotal circumference is directly correlated to body weight and testosterone concentration, irrespective of which season the animals were born in. We were therefore successful in achieving our aim of determining the effect of the season of birth on the onset of sexual maturation of young Boer goat males in the semiarid region of the northeast of Brazil.

\section{References}

Ahmad, N., Noakes, D.E. \& Wilson, C.A., 1996. Secretory profiles of LH and testosterone in pubescent male goat kids. Small Rumin. Res. 21, 51-56.

Auclair, D., Sowerbutts, S.F. \& Setchell, B.P., 1995. Effect of active immunization against oestradiol in developing ram lambs on plasma gonadotrophin and testosterone concentrations, time of onset of puberty and testicular blood flow. J. Reprod. Fert. 104, 7-16.

Azevedo Neto, J., 2005. Efeitos de dietas contendo suplementação protéica e lipídica sobre concentrações hormonais e qualidade do sêmen de caprinos no semi-árido. Doctor's thesis, Univeridade Federal Rural de Pernambuco, Brazil. (In Portuguese).

Bongson, T.A., Jainudeen, M.R. \& Zahrah, A.S., 1982. Relationship of scrotal circumference to age, body weight and onset of spermatogenesis in goats. Theriogenology 18, 513-524.

De La Vega, A., Ruiz, R. \& Wilde, O., 2001. Relación de la circunferencia escrotal con algunos parámetros de calidad seminal en caprinos Criollos de Tucumán (Argentina). Zootecnia Trop. 19, 455-463. (In Spanish).

Delgadillo, J.A. \& Chemineau, P., 1992. Abolition of the seasonal release of luteinizing hormone and testosterone in Alpine male goats (Capra hircus) by short photoperiodic cycles. J. Reprod. Fertil. 94, 45-55.

Eastone, J.A. \& Decker, C.F., 1997. New-onset diabetes mellitus associated with use of protese inhibitor. Ann. Intern. Med. 127, 947 (Abstr.).

Eloy, A.M.X. \& Santa Rosa, J.S., 1998. Perfis plasmáticos de testosterona durante a puberdade de machos caprinos da raça Moxotó. Pesquisa Agropecuária Brasileira, 33, 1645-1652. (In Portuguese).

Elwishy, A.B. \& Elsawaf, S.A., 1971. Development of sexual activity in male Damascus goats. Indian J. 
Anim. Sci. 41, 350-356.

Girão, R.N., Nascimento, H.T.S., Vasconcelos, V.R., Medeiros, L.P. \& Girão, E.S, 1996. Puberdade de machos caprinos da raça Marota e de mestiços da raça: Anglo-Nubiana, no estado do Piauí. Proceedings of the Sociedade Brasileira de Zootecnia. Ceará, Brasil. 33, 557-559. (In Portuguese).

Hafez, E.S.E., 2004. Anatomia da Reprodução Masculina. In: Hafez, E.S.E. \& Hafez, B., Reprodução Animal. $7^{\text {th }}$ ed. Manole, Barueri, Brazil. pp. 3-12. (In Portuguese).

Hulet, C.V. \& Shelton, M., 1988. Ovinos e Caprinos. In: Reprodução Animal. Ed. Hafez, E.S.E. Manole, São Paulo. pp. 397-411. (In Portuguese).

Jimeno, V., Castro, T. \& Rebollar, P.G., 2001. Interacción-Reproducción en ovinos de leche. XVII Curso de Especialización FEDNA, 131-160. (In Portuguese).

Johnstone, I.L., 1948. The growth and development of the penis in sheep. Aust. Vet. Jour. 24, 86-88.

Louw, D.F.J. \& Joubert, D.M., 1964. Puberty in the male Dorper sheep and Boer goat. S. Afr. J. Agric. Sci., 7, 509-520.

Macmillan, K.L. \& Hafs, H.D., 1969. The reproductive tract of Holstein bulls from birth through puberty. J. Anim. Sci. 28, 233-239.

Madani, M.O.K. \& Rahal, M.S., 1988. Puberty in Libyan male goats. Anim. Reprod. Sci. 17, 207-216.

Maia, M.S., 1990. Puberdade em cabritos mestiços (Gurguéia x Parda) em Teresina-PI. Monography, Univerainy seasonidade Estadual do Ceará, Brazil. (In Portuguese).

Muduuli, D.S., Sanford, L.M., Palmer, W.M. \& Howland, B.E., 1979. Secretory patterns and circadian and seasonal changes in luteinizing hormone, follicle stimulating hormone, prolactin and testosterone in the male pygmy goat. J. Anim. Sci. 49, 543-553.

Nunes, J.F., 1982. Fisiologia sexual do macho caprino. Circular Técnica, EMBRAPA-CNPC, 5, 41. (In Portuguese).

Olster, D.H. \& Foster, D.L., 1986. Control of gonadotropin secretion in the male during puberty: A decrease in response to steroid inhibitory feedback in the absence of an increase in steroid-I independent drive in the sheep. Endocrinology 118, 2225-2234.

Passing, H. \& Bablok, W., 1983. A new biometrical procedure for testing the equality of measurements from two different analytical methods. J. Clin. Chem. Clin. Biochem. 21, 709-720.

Scott, C.J., Kuehl, D.E., Ferreira, S.A., Gary, L. \& Jackson, G.L., 1997. Hypothalamic sites of action for testosterone, dihydrotestosterone and estrogen in the regulation of luteinizing hormone secretion in male sheep. Endocrinology 138, 3686-3694.

Silva, S.C.B., 2000. Caracterização Histológica e seminal do desenvolvimento sexual de caprinos Saanen, criados em sistema intensivo. MSc thesis, Univerainy seasonidade Federal de Minas Gerais, Brazil. (In Portuguese).

Simplício, A.A., Riera, G.S., Nelson, E.A. \& Foote, W.C., 1988. Puberdade em caprinos da Raça Moxotó no Nordeste brasileiro. Rev. Bras. Reprod. Anim. 12, 121-126. (In Portuguese).

Skinner, J.D., 1970. Post-natal development of the reproductive tract of the male Boer goat. Agroanimalia 2, 177-180.

Traldi, A.S., 1983. Aspectos físicos e morfológicos do sêmen de caprinos da raça Moxotó da puberdade à maturidade sexual. MSc thesis, Univerainy seasonidade Federal de Minas Gerais, Brazil. (In Portuguese).

Trejo, G.A., Márquez, M.M.D. \& Salazar, C.E., 1988. Testis growth, seminal quality, sperm reserves and testosterone production in Alpine kidry season treated hormonally around puberty. In: International Congress on Animal Reproduction and Artificial Insemination, 11, University College, Dublin, Ireland. v3, p. 386 (Abstr.).

Wiggins, E.L. \& Terril, C.E., 1953. Variation in penis development in ram lambs. J. Anim. Sci. 12, 524-535. 